\section{Krzysztof Pilarczyk}

krzysztof.pilarczyk@uj.edu.pl

Uniwersytet Jagielloński

ORCID: 0000-0001-9283-1204

DOI: http://dx.doi.org/10.12775/BPTh.2021.003
Biblica

et

Patristica

Thoruniensia

14 (2021) 1: 65-95

ISSN (print) 1689-5150

ISSN (online) 2450-7059

\title{
Szymon Mag w Dziejach Apostolskich (8,4-25) Miejsce narracji w strukturze księgi i jej znaczenie
}

\author{
Simon Magus in Acts (8:4-25) \\ The role and significance of narrative \\ in the structure of the book
}

Streszczenie: Przedmiotem artykułu jest postać Szymona Maga, przedstawiona w kanonicznych Dziejach Apostolskich, znanego także z innych źródeł wczesnochrześcijańskich jako pregnostyka. Autor w pierwszej części przedstawia perykopę 8, 4-25 w kontekście literackim księgi, historię badań związanych z jej redakcją, a następnie podejmuje próbę odpowiedzi, na ile Łukaszowe ujęcie jest historyczne. W drugiej części artykułu ukazuje kontekst kulturowy narracji Dz 8, 4-25, religijne uwarunkowania mieszkańców miasta Samarii (Sebaste), ich przywiązanie do magii, a na tym tle postać Szymona Maga. Przedmiotem jego zainteresowania staje się także antyczna magia pozostająca w opozycji do religii oraz napięcia, jakie powstają pomiędzy nią a wczesnochrześcijańskim rozumieniem cudów (znaków) oraz głoszoną Ewangelią Jezusa Chrystusa. W podsumowaniu ukazuje znaczenie Szymona Maga z Łukaszowego przekazu dla drugiej generacji chrześcijan (adresatów Dziejów) oraz performatywny charakter jego narracji.

Abstract: The subject of the article is the figure of Simon Magus, presented in the ca-
nonical Acts of the Apostles, also known from other early Christian sources as preg-
nostic. In the first part, the author presents pericope $8: 4-25$ in the literary context of
the book, the history of research related to its editing, and then attempts to answer
to what extent Luke's approach is historical. The second part of the article is devoted
to the cultural context of the narrative in Acts $8: 4-25$, the religious conditions of the
inhabitants of the city of Samaria (Sebaste), their attachment to magic, and against this
background the figure of Simon Magus. The subject of his interest is also ancient magic
that is in opposition to religion and the tensions that arise between it and the early
Christian understanding of miracles (signs) and the preached Gospel of Jesus Christ.
Summing up, the text emphasizes the importance of Simon Magus from Lukes message 
for the second generation of Christians (addressees of the Acts) and the performative nature of his narrative.

Słowa kluczowe: Dzieje Apostolskie; Szymon Mag; gnoza; magia; chrześcijaństwo.

Keywords: Acts of the Apostles; Simon Magus; gnosis; magic; Christianity.

Prawdopodobnie pierwotny przekaz pisemny o Szymonie Magu znajduje się w kanonicznej księdze Nowego Testamentu - Dziejach Apostolskich $(8,4-25)^{1}$. Wymienionego w niej Szymona Maga traktuje się na ogół jako postać historyczną ${ }^{2}$, choć były również antyczne świadectwa, które przeczyły jego istnieniu. W szerszych badaniach wczesnego chrześcijaństwa postrzegany był jako herezjarcha, założyciel sekty gnostyckiej szymonian ${ }^{3}$, która powstała w środowisku samarytańskim i rozpowszechniła się w II-III wieku, w tym na terenie Rzymu. Jej doktryna, wynikająca z łączenia elementów mitologii, platonizmu i judaizmu, uwypukla sprzeciw mocy pośredniczących wobec Boga i ludzi, traktuje ciało ludzkie jako miejsce uwięzienia pierwiastka boskiego, Szymona Maga uważa za bóstwo i przypisuje mu moce zbawcze. Dlatego Szymon (i szymonianie) traktowany był przez Ojców Kościoła jako archetyp późniejszych herezji ${ }^{4}$, a Jean Daniélou, badacz wczesnego chrześcijaństwa, widział w nim

1 Por. S. Haar, Simon Magus: the First Gnostic? (Beihefte zur Zeitschrift für die neutestamentliche Wissenschaft und die Kunde der älteren Kirche, Bd. 119), Berlin-New York 2003, s. 71. O pierwszeństwo $\mathrm{z}$ nimi, choć jest to mało prawdopodobne, mógłby rywalizować zapis o Szymonie, jaki się znalazł u Justyna Męczennika w 1 Apologiae (I, 26, 1-3, 56, 1-2), których pierwsza część datowana jest na ok. 150 roku - zob. Justyn Męczennik, w: Nowy słownik wczesnochrześcijańskiego piśmiennictwa, wyd. 2 przepr. i uzup. Marek Starowieyski przy współ. Wojciecha Stawiszyńskiego, Poznań 2018, s. 567. Na temat datacji Dziejów Apostolskich zob. K. Pilarczyk, Wokół problemu datacji Dziejów Apostolskich, „Wrocławski Przegląd Teologiczny” 23, 2015, nr 3, s. 75-94. Autor opowiada się za ich datowaniem na pierwszą połowę II wieku, tak jak to przedstawiał już wcześniej F. Gryglewicz - zob. idem Dzieje Apostolskie, w: Encyklopedia katolicka, t. 4, Lublin 1983, kol. 576.

2 Por. Acts and Christian Beginnings: the Acts Seminar Report, ed. by D.E. Smith and J.B. Tyson, Salem, Oregon 2013, s. 98. Oddzielnym zagadnieniem jest historyczność narracji o Szymonie w ujęciu autora Dziejów.

3 Por. W. Chrostowski, Szymonianie, w: Encyklopedia katolicka, Lublin 2013, t. 19, kol. 231-232.

4 Zob. A.Z. Zmorzanka, Szymon Mag, w: Powszechna encyklopedia filozofii, Lublin 2009, t. 9, s. 318-320; P. Kochanek, Szymon Mag, Encyklopedia katolicka, Lublin 2013, t. 19, kol. 229-230; B. Aland, Die Gnosis, Stuttgart 2014, s. 155-162; Ch. Markschies, Die Gnosis, 
kluczowe ogniwo pośrednie między przedchrześcijańską gnozą judeosamarytańską (pregnozą) a chrześcijańskim gnostycyzmem ${ }^{5}$.

Przez autora Dziejów Apostolskich został on ukazany jako ten, który pod wpływem nauczania diakona Filipa przyjął chrzest, a następnie pragnął kupić od apostołów Piotra i Jana władzę udzielania mocy Ducha Świętego przez gest nałożenia rąk. Ponieważ spotkał się z odmową ze strony Piotra, stał się jego wrogiem. Od tego przekazu bierze nazwę szersze zjawisko nabywania godności kościelnych, sakramentów i dóbr duchowych w zamian za dobra doczesne. Określa się je mianem symonii (od Szymona) czyli świętokupstwa ${ }^{6}$.

Można się zastanawiać, dlaczego epizod o Szymonie Magu został włączony do Dziejów Apostolskich, w jakim kontekście literackim i historycznym został umieszczony oraz jakim celom miała służyć narracja księgi z epizodem Szymona, skierowanej w połowie drugiego wieku głównie do etnochrześcijan? Nie bez znaczenia jest również szerszy kontekst kulturowy działalności Szymona, uprawiającego magię, i próbującego ją włączyć jako praktykę w chrześcijańską misję ewangelizacyjną.

\section{Kontekst literacki perykopy}

Struktura literacka Dziejów daje się ująć w siedem części :

- początek i rozwój Kościoła w Jerozolimie (Dz 1-5);

- napięcia stworzone przez judeochrześcijan hellenistów i prześladowania Kościoła (Dz 6-7);

- szerzenie Dobrej Nowiny o Jezusie Chrystusie w Samarii oraz środowiskach pogańskich aż po syryjską Antiochię (Dz 8-12);

- rozwój misji od Antiochii po Cypr i Azję Mniejszą (Dz 13-15);

4. Aufl., München 2018, s. 76-80; A.Z. Zmorzanka, Szymon Mag, w: Nowy słownik wczesnochrześcijańskiego piśmiennictwa, wyd. 2 przepr. i uzup. przyg. Marek Starowieyski przy współ. Wojciecha Stawiszyńskiego, Poznań 2018, s. 907-908.

5 Por. J. Daniélou, Teologia judeochrześcijańska. Historia doktryn chrześcijańskich przed soborem nicejskim, przekł. S. Basista, Kraków 2002, s. 84-90. Zob. także A. Walburn, Początki chrześcijaństwa. Esseńskie misterium, gnostyckie objawienie, chrześcijańska wizja, Warszawa 1998, s. 65-68.

6 Zob. A Miziński, Symonia, w: Leksykon Prawa Kanonicznego, red. M. Sitarz, Lublin 2019, kol. 2686-2689.

7 Por. F.F. Bruce (jm), Dzieje apostolskie, [w:] Słownik wiedzy biblijnej, red. nauk. B.M. Metzger, M.D. Coogan, wyd. 3, Warszawa 1999, s. 128. 
- rozstrzygnięcia dotyczące prowadzonej misji wśród pogan (Dz 15,1$-16,5)$;

- misja Pawła i jego towarzyszy w prowincjach nad Morzem Egejskim (Dz 16,6-19,20);

- obszerny epilog Pawłowej działalności (Dz 19,21-28,31).

Księga opisuje zatem wybrane epizody z szerzenia Dobrej Nowiny (Ewangelii Jezusa Chrystusa), począwszy od Jerozolimy, a skończywszy na Rzymie. Epizod o Szymonie Magu przynależy do trzeciej z wymienionych części, traktującej o prowadzonej ewangelizacji w Samarii oraz w innych środowiskach politeistycznych Palestyny (Dz 8-12). Rozpoczyna się ona jako następstwo prześladowań Żydów hellenistów w Jerozolimie po ukamienowaniu diakona Szczepana. Wówczas żydowscy helleniści opuszczają Judeę i udają się na zachód do Samarii, a następnie na północ aż do Antiochii. Tą drogą podążają również apostołowie, w tym wzmiankowani w ósmym rozdziale Dziejów Piotr i Jan. Autor Dziejów ujmuje opis misji wśród pogan (treść ósmego rozdziału) w następującej kolejności:

- prześladowanie Żydów hellenistów w Jerozolimie $(8,1-3)$;

- działalność diakona Filipa w Samarii (8,4-13): passus od w. 9 dotyczy Szymona Maga, którego Filip ochrzcił;

- działalności apostołów Piotra i Jana (8,14-25): duża część dotyczy Szymona, który pragnie kupić od Piotra władzę udzielania Ducha Świętego;

- nawrócenia przez Filipa dworzanina etiopskiego (8,26-40).

W narracji Dziejów działalność misyjna judeochrześcijan poza Jerozolimą ilustrowana jest przez epizod związany z ewangelizatorem Filipem, który naucza w Samarii, w tym nawraca i chrzci etiopskiego prozelitę, znajdującego się w drodze do Gazy. W tym kontekście wprowadzony jest do narracji Szymon, który staje się wkrótce przeciwnikiem Filipa (i Piotra). W Dziejach został scharakteryzowany w następujący sposób:

Pewien człowiek, imieniem Szymon, który dawniej zajmował się czarną magią $\left[\mu \alpha \varepsilon^{\prime} \omega^{\omega} \omega v^{8}\right]$, wprawiał w zdumienie lud Samarii, mówiąc, że jest kimś niezwykłym. Poważali go wszyscy od najmniejszego do największego: 'ten jest mocą Bożą, którą zowią wielką’ - mówili. A liczyli się z nim dlatego, że już od dłuższego czasu wprawiał ich w podziw swoimi magicznymi sztukami.

8 Znany był jako mag ( $\mu a ́ \gamma o \varsigma)$. 
Działalność Filipa wywarła na mieszkańcach Samarii duże wrażenie. Jego nauczanie skłoniło wielu do przyjęcia chrztu. Przyjął go również Szymon, który następnie towarzyszył Filipowi, podziwiając czynione przez niego cuda i znaki (w. 13).

Na wieść o sukcesach ewangelizacyjnych w Samarii, przybyli tam również apostołowie Piotr i Jan, udzielając ochrzczonym przez nałożenie rąk Ducha Świętego, który na nich jeszcze nie zstąpił. „Byli jedynie ochrzczeni w imię Pana Jezusa” (w. 16). Gdy Szymon zobaczył, że przez włożenie rąk otrzymywali oni Ducha Świętego, przyniósł apostołom pieniądze, aby i on mógł posiąść taką władzę. Wówczas Piotr przeklął Szymona, ponieważ - jak powiedział - serce jego nie jest prawe wobec Boga. Jednocześnie wezwał go do nawrócenia od grzechu, a Pan może odpuści mu jego winę.

Narracja ma skłonić czytelnika do zastanowienia się nad czynem popełnionym przez Szymona, który później w kulturze chrześcijańskiej zostanie jednoznacznie potępiony (symonia). Jego zaś samego - podzielając ocenę znawcy herezji w pierwotnym Kościele, Ireneusza, biskupa Lyonu - nazywano pierwszym heretykiem i założycielem gnostycyzmu9', który stanowił zagrożenie dla chrześcijaństwa od II wieku.

\subsection{Z badań nad historią redakcji perykopy}

W opinii niektórych badaczy Dziejów Apostolskich (np. Ernsta Haenchena i Gerda Lüdemanna) ich autor, pragnąc zdyskredytować znanego na przełomie I i II wieku Szymona, który był znanym wówczas zwolennikiem gnozy, świadomie przekształcił go w osobę samarytańskiego maga, któremu przypisywano cechy boskie ${ }^{10}$. Niemniej krytycy ich tezy wskazują, że istnieją poważne problemy metodologiczne i historyczne, gdy analizuje się ósmy rozdział Dziejów,

9 Zob. Ireneusz z Lyonu, Adversus haereses, przekł. Jarosław Brylowski, Pelplin 2018: „Tenże więc Szymon Samarytanin, od którego biorą wszystkie herezje, utworzył swą sektę... (I, 23, 2). Zwolennicy Szymona „samych siebie określają jako Symonitów, przyjąwszy nazwę od imienia twórcy owej fałszywej doktryny. To od nich wzięła początek nauka błędnie nazwana gnozą, co łatwo zresztą poznać po ich własnych twierdzeniach" (I, 23, 4) - s. 72-74. Współcześnie Szymon traktowany jest jako pregnostyk.

10 E. Haenchen, The Acts of the Apostles. A Commentary, Oxford 1971, s. 307; G. Lüdemann, Untersuchungen zur simonianischen Gnosis (GTA 1), Göttingen 1975, s. 42. Por. C. Barrett, A Critical and Exegetical Commentary on the Acts of the Apostles, vol. 1, Preliminary Introduction and Commentary on Acts I-XIV, Edinburgh 1994, s. 407. 
niepozwalające na tak arbitralne sądy. Wiedza autora Dziejów na temat herezji w pierwotnym Kościele, nie odpowiada tej, którą posiadali później żyjący herezjolodzy w II i III wieku, egzemplifikowani przez wyżej przywołanego już Ireneusza z Lyonu, a także innych: Hegezypa, Tertuliana czy Hipolita. Trafnie podsumował to Kurt Rudolf pisząc, że późniejsze obrazy Szymona są nie do pogodzenia z najwcześniejszymi świadectwami o nim, jeżeli nie chce się dokonywać na nich gwałtu lub ponieść bujnej wyobraźni ${ }^{11}$.

Mając na uwadze te wstępne opinie o Szymonie, badany fragment Dziejów 8,4-25 należy poddać szczegółowej analizie krytyczno-literackiej, która pomogłaby odkryć redakcję tegoż pisma, wskazać ewentualne wykorzystane źródła oraz własny wkład autora i jego osąd o wprowadzonym do narracji Szymonie. Czy w jego przekonaniu był on (pre)gnostykiem, tak jak definiowali go późniejsi herezjolodzy, czy tylko był nim w jakimś ograniczonym, szczególnym sensie, i czy za użytym na jego określenie słowem $\mu a ́ \gamma o \varsigma$ (nie pojawia się ono w Dziejach, lecz dopiero w późniejszej literaturze pstrystycznej) kryje się coś jeszcze innego? W badaniach tych pomocne jest studium S. Haara, cytowane już powyżej ${ }^{12}$, oraz komentarz do Dziejów Apostolskich Richarda J. Dillona, uwzględniający skróconą historię redakcji tej perykopy ${ }^{13}$.

W XIX wieku szkoła tybingeńska broniła obrazu Szymona opartego na pseudoklementyńskim ${ }^{14}$ przekazie, według którego był on opisany na wzór charakterystyczny dla Pawła. Sądzono, że Łukasz celowo miał ukrywać źródło, którym się posługiwał przy redakcji Dz 8,4-25. W pierwotnej narracji autorzy tybingeńscy dostrzegali inne pierwszoplanowe postacie, opisane na wzór Piotra w opozycji do Pawła.

Na przełomie XIX i XX wieku Hans Waitz doszukiwał się w Dz 8,4-25 innego pierwowzoru. Według niego wersety 5-13 opisywały w rzeczywistości działalność Piotra, co można rzekomo wywnioskować z apokryficznych Dziejów Piotra (II wiek), które nie odnoszą się do kanonicznych Dziejów Apostol-

11 K. Rudolph, Simon - Magus oder Gnosticus? Zum Stand der Debatte, „Theologische Rundschau" 42, 1977, s. 289.

12 Por. S. Haar, Simon Magus: the First Gnostic?, s. 73-79.

13 Zob. R.J. Dillon, Dzieje Apostolskie, w: Katolicki komentarz biblijny, red. R.E. Brown, J.A. Fitzmyer, R.E. Murphy; red. wyd. pol. W. Chrostowski, Warszawa 2001, s. 1209-1210 (ad Dz 8, 4-25).

14 Por. Ps-Klemens, Recognitiones, passim. Zob. A. Tuzlak, The Magician and the Heretic: the Case of Simon Magus, w: Magic and Ritual in the Ancient World, Brill 2001, s. $416-426$. 
skich, lecz do jakiegoś pierwotniejszego źródła, znanego zapewne Łukaszowi ${ }^{15}$. Według niego, człowiekiem, który już w Palestynie zdemaskował Szymona jako czarnoksiężnika i doprowadził do wypędzenia go z Judei, był Piotr. Dołączony do Łukaszowego opowiadania z ósmego rozdziału Filip jest - według niego postacią zastępczą, wprowadzoną tylko dlatego, że w w. 1 odnotował, iż po męczeństwie Szczepana wybuchło w Kościele jerozolimskim wielkie prześladowanie, na skutek którego wszyscy, poza apostołami, rozproszyli się po okolicach Judei i Samarii. Autor Dziejów musiał zatem zastąpić Piotra Filipem, aby utrzymać spójność narracji w Dz 8,4-40 ${ }^{16}$.

Natomiast Julius Wellhausen przyjął przeciwne stanowisko, twierdząc, że tak naprawdę w analizowanej narracji Łukaszowej wśród wymienionych postaci „intruzem” jest Piotr. Według niego po w. 13 („Uwierzył również sam Szymon, a kiedy przyjął chrzest, towarzyszył wszędzie Filipowi i zdumiewał się bardzo na widok dokonywanych cudów i znaków”), następował w. 18b („przyniósł im [mu] pieniądze”), co miałoby oznaczać, że złożył ofertę pieniężną Filipowi, aby i on mógł uzdrawiać chorych ${ }^{17}$. Zaś werset $19 b$ („aby każdy, na kogo położę ręce, otrzymał Ducha Świętego") jest dodatkiem, w związku z czym na-

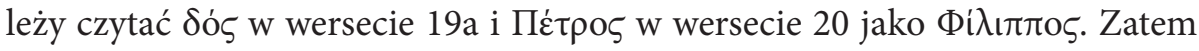
w pierwotnej wersji opowiadania Szymon prawdopodobnie zapytał samego Filipa, czy mógłby kupić od niego dar czynienia cudów, a ten mu odmówił. Przydany opowiadaniu nowy Piotrowy kontekst sytuuje odmowę w atmosferze przekleństwa i wezwania do nawrócenia, ale bez określenia recepcji tych słów (z narracji nie wynika, co się stało z Szymonem; czy zrozumiał swój grzech i jego wina została przebaczona?).

Otto Bauernfeind, widząc trudność rozwikłania przeplatających się wątków z tradycji i kompozycji samego Łukasza, doszedł do wniosku, że autor Dziejów połączył historię sukcesu misyjnego Filipa w Samarii z opowiadaniem zaczerpniętym z tradycji o spotkaniu Szymona i Piotra. Za specyficznie Łukaszowy element opowiadania uznał natomiast połączenie Szymona z Filipem ${ }^{18}$.

15 Zob. Dzieje Piotra Apostoła i Szymona, tłum. Z. Izydorczyk i M. Bielewicz; oprac. Z. Izydorczyk, „Warszawskie Studia Teologiczne” 16: 2003, s. 101-150.

16 H. Waitz, Die Quelle der Philippusgeschichten in der Apostelgeschichte, „Zeitschrift für Neutestamentlichen Wissenschaft" 7: 1906, s. 352-353.

17 Por. J. Wellhausen, Kritische Analyse der Apostelgeschichte (AGG 15), Berlin 1914, s. 25.

18 O. Bauernfeind, Die Apostelgeschichte (ThHK 5), Leipzig 1939, s. 124. 
Oscar Cullmann doszukiwał się w w. 14-17 późniejszej tradycji niż ta, która mówiła o spotkaniu Filipa z Szymonem. To źródło opisywało interwencję Piotra i Jana, którzy jako przedstawiciele kolegium Dwunastu zostali wysłani do autoryzowania misji „hellenistycznej” w Samarii. Ta ich interwencja, o której pisał Cullmann, została - według niego - niezależnie potwierdzona w Ewangelii Jana 4,38: „Ja [Jezus] was wysłałem, abyście żęli to, nad czym wy się nie natrudziliście. Inni się natrudzili, a wy w ich trud weszliście"19.

Natomiast Ernst Haenchen utrzymywał, że opowiadania o Filipie i Szymonie były pierwotnie oddzielne, a połączył je dopiero Łukasz, aby wyeksponować wyższość daru Ducha oraz dominację Filipa nad Szymonem ${ }^{20}$. Podzielił również pogląd Wellhausena na temat złożonej przez Szymona propozycji finansowej Filipowi. Za Łukaszowy konstrukt uznał wprowadzenie Piotra do 8,14-25. Jego zdaniem narracja o Szymonie pozwoliła autorowi Dziejów (podobnie jak w 13,6-12 i 19,13-20) zilustrować przekonanie o wyższości cudów chrześcijańskich nad praktykami magicznymi na obszarze szerzenia ewangelii oraz mocy Boga nad demoniczną magią ${ }^{21}$.

Hans Conzelmann dostrzegł w Dz 8,4-25 aż trzy warstwy pochodzące z tradycji: (1) opowieść o misyjnym sukcesie Filipa w Samarii, (2) wątek dotyczący Filipa i Szymona oraz (3) przekaz łączący epizod Filipa z epizodem o Piotrze i Janie ${ }^{22}$, co oznaczało większy stopień kompilacji dokonanej przez Łukasza.

Gerhard Schneider powtórzył końcową tezę Haenchena o ilustrowaniu w Dziejach wyższości cudów chrześcijańskich: „Główną funkcją opowieści o Szymonie Magu w tym kontekście jest to, że ilustruje ,wyższość cudów chrześcijańskich nad magiczną naturą środowiska"'23. Za pierwotne tradycje, które znał Łukasz, uważał dwie - opowiadanie o Filipie w 8,4-12 i chrzest prozelity z Etiopii w 8,26-40. Natomiast na ich przedłużeniu znalazła się interpolacja opowiadająca o działalności Piotra i Jana, zaś epizod o Szymonie połączył 8,4-13 i 8,14-25. Schneider podejrzewał, że autor Dziejów wybrał przekaz o Filipie z większego zbioru podobnych opowiadań, do którego dodano epizod

19 O. Cullmann, Samarien und die Anfange der christlichen Mission. Wer sind die

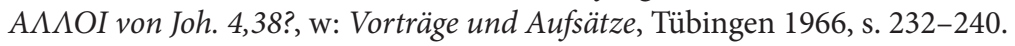

20 E. Haenchen, The Acts of the Apostles. A Commentary, s. 307.

21 Ibidem, s. 306.

22 H. Conzelmann, Acts of the Apostles, trans. J. Limberg, A.T. Kraabel, D.H. Juel, Philadelphia 1987, s. 64.

23 G. Schneider, Die Apostelgeschichte (Herder Theologischer Kommentar zum Neuen Testament 5), Bd. I, Freiburg-Basel-Wien 1980, s. 485. 
o Szymonie złożony z dwóch odrębnych tradycji: (1) opisu jego nawrócenia i chrztu oraz (2) ofiary pieniężnej za prawo do udzielania Ducha Świętego. Połączenie ich nastąpiło wcześniej nim Łukasz je wykorzystał. Schneider z aprobatą odniósł się do wniosków wyprowadzonych przez Haenchena, jakoby tradycję o Szymonie oferującym pieniądze należało łączyć z Filipem. Był on przekonany, że w. 14-17 są „czystym wymysłem Łukasza”, pozwalającym powiązać ze sobą dwie początkowe tradycje. Uważał też za możliwe dodanie przez Łukasza do opowiadania przekazu o przybyciu do Samarii Piotra i Jana. W rzeczywistości mogły to być dwie oddzielne misje ewangelizacyjne realizowane na tym obszarze, wspierane przez Jerozolimę $e^{24}$.

Niezwykle ważna jest konstatacja, dotycząca historii redakcji ósmego rozdziału Dziejów, której dokonał Gerd Lüdemann, poparta analizą statystyczną słownictwa i składni Dz 8,4-25. Według niego cała ta sekcja jest wyraźnie Łukaszowa, zarówno pod względem języka, jak i treści. Widząc w Łukaszu autora obu części $(8,14-17$ i 8,18-24), odszedł od wniosków wyprowadzanych przez Wellhausena, Haenchena, Conzelmanna i Schneidera, którzy postulowali jakąś wcześniejszą tradycję, stojącą za wersami 18-24. Lüdemann przedstawił własną argumentację, wykazując, że źródło Łukasza odzwierciedla jedną warstwę tradycyjnego materiału ${ }^{25}$, który obejmował zarówno sukces misyjny Filipa, jak i konflikt między nim a Szymonem.

Dietrich-Alex Koch uważał, że w Dz 8,18-24 można odkryć tradycję leżącą u podstaw narracji o Piotrze i Szymonie ${ }^{26}$. Zidentyfikował w Dz 8,4-25 - jak mniemał - trzy elementy przedłukaszowe: (1) niejednolitą relację o działalności misyjnej Filipa w Samarii, (2) opowieść o uprawianiu magii przez Szymona i pozyskiwaniu przez niego zwolenników, (3) oraz epizod o konfrontacji Piotra z Szymonem. W jego argumentacji dwa pierwsze elementy zyskały dostateczne uzasadnienie egzegetyczne, natomiast trzeci najsłabsze. Dlatego skłonny był widzieć w Dz 8, 22-24 Łukaszowy rys, ponieważ ustna tradycja, traktująca o ostrym konflikcie między Piotrem i Szymonem, byłaby bardziej jednoznaczna, a w przekazie Łukaszowym taka nie jest.

24 Ibidem, s. 480.

25 G. Lüdemann, Early Christianity according to the Traditions in Acts. A Commentary, Minneapolis 1989, s. 93-102.

26 D.-A. Koch, Geistbesitz, Geistverleihung und Wundermacht. Erwägungen zur Tradition und zur lukanischen Redaktion in Act 8,5-25, „Zeitschrift für Neutestamentlichen Wissenschaft" 77, 1986, s. 67-80. 
Charles Barrett wyraził przekonanie, że chociaż Dz 8,4-25 wyglądają na jedno połączone opowiadanie, $\mathrm{w}$ rzeczywistości składają się z kilku części składowych: w. 4-8 opisują dzieło Filipa w mieście Samarii, w. 9-13 traktują o kontynuacji misji przez Filipa, w wyniku której nawróceni zostali zwolennicy Szymona Maga i on sam, w. 14-17 stanowią fragment redakcyjny o misji Piotra i Jana, w końcu w. 18-24 mówią o skarceniu przez Piotra Szymona, a w. 25 jest redakcyjną konkluzją ${ }^{27}$.

\subsection{W poszukiwaniu historycznego obrazu Szymona}

Celem Łukasza było napisać uporządkowane opowiadanie (Łk 1,3; Dz 1,1) o zdarzeniach, które się dokonały, a dotyczyły w pierwszej jego księdze osoby Jezusa Chrystusa, ,tak jak nam przekazali ci, którzy od początku byli naocznymi świadkami i sługami słowa” (Łk 1,2), w drugiej zaś świadków Chrystusa, którzy wypełniali swą misję ,w Jerozolimie i w całej Judei, i w Samarii, i aż po krańce ziemi” (Dz 1,8). Czy tylko chodziło w tym zamiarze o przypomnienie i utrwalenie w zbiorowej pamięci chrześcijan dokonanych zdarzeń? Z pewnością jego cel jest też hermeneutyczny i kerygmatyczny. Nie chodziło Łukaszowi o odnotowanie tylko tego, że coś się wydarzyło, ale pragnął zakomunikować, jakie znaczenie posiadają opisane wydarzenia oraz nadać im charakter ewangelicznego orędzia. Chciał zatem temu przekazowi zapewnić autorytet. Oprócz opisania „rzeczy, które się między nami wydarzyły”, co dla kolejnych pokoleń chrześcijan, które nie znały ich $\mathrm{z}$ autopsji, ma charakter informujący, mają one - co ważniejsze - charakter objaśniający, a zarazem definiujący je, tożsamościowy i legitymizujący ${ }^{28}$. Chrześcijaństwo potrzebowało takiej definicji, ponieważ $\mathrm{w}$ pierwszym pokoleniu istniało szerokie spektrum wierzeń i praktyk manifestujących się w separatystycznych grupach o ekskluzywnych roszczeniach. Chrześcijaństwo potrzebowało tożsamości, ponieważ po zerwaniu z partykularyzmem żydowskim, nowa religia nie była już przywiązana do określonej grupy etnicznej, w przeciwieństwie do innych religii w starożytnych krajach śródziemnomorskich. W końcu potrzebowało legitymizacji, ponieważ żaden ruch religijny ani grupa reprezentująca określony nurt filozoficzny nie mogła być wiarygodna, jeżeli nie była zakorzeniona w starożytności. Łukasz

27 Ch. Barrett, A Critical and Exegetical Commentary on the Acts of the Apostles, 1 vol., Preliminary Introduction and Commentary on Acts I-XIV, Edinburgh 1994, s. 398.

28 D.E. Aune, The New Testament in Its Literary Environment, Philadelphia 1987, s. 137. 
zapewnił tę legitymizację, ukazując żydowskie pochodzenie chrześcijaństwa i podkreślając boską opatrzność, która znajdowała odzwierciedlenie w każdym aspekcie rozwoju i ekspansji wczesnych kościołów.

Przy ocenie dostępnych dowodów wydaje się wysoce prawdopodobne, że narracja o podróży misyjnej Filipa do Samarii jest zależna od tradycji przedłukaszowych, zawierających między innymi cykl opowieści o Filipie. Ponadto - jak sugerował Lüdemann ${ }^{29}$ - jest mało prawdopodobne, że Łukasz był pierwszym, który połączył Szymona i Filipa, ponieważ niejako bez Filipa mógłby bezpośrednio przejść do opisu konfrontacji między Piotrem i Szymonem Magiem. Stąd może zostać wyprowadzony wniosek, że istniały jakieś (ustne?) tradycje o działalności Filipa i niejakiego Szymona w Samarii. Łukasz je wykorzystał i dodał jeszcze inne szczegóły o Szymonie i Piotrze apostole, być może pochodzące $z$ wielu źródeł. To dopiero zaowocowało narracją, która zawiera pewne niezręczności w w. 9-11 dotyczące sekwencji czasowej (tzw. Rückblende - wspomnienia). W wersetach tych zawarty jest opis wcześniejszej działalności Szymona przed podaniem szczegółów o nawróceniu Maga, odnotowanych w w. 12-13.

Chociaż przekazany w Dziejach tekst 8,4-25 zapewne nie zawiera całości ustnej tradycji o Filipie i Szymonie, o czym można wnioskować na podstawie szczegółowszej historii Szymona, która pojawiła się w II wieku i później, to widocznie Łukasz nie uważał za stosowne ich przywołać w kontekście swojej połączonej relacji o osobach Filipa, Szymona i Piotra. Jego cała narracja, a szczególnie w. 14-24, są przebudowaną przez niego konstrukcją. Jest ona tylko jakąś częścią ustnego przekazu należącego do najwcześniejszej historii chrześcijaństwa. W ujęciu Łukasza forma, jaką jej nadał, to zaledwie migawka, aby można się zastanowić i przeanalizować ją przy pomocy dostępnych narzędzi.

Analizy tej dokonał Haar, ukazując język i strukturę interesującej nas perykopy $^{30}$. Skłania się on do hipotezy większości badaczy, że w. 4-25 ukształtowane zostały ostatecznie przez Łukasza, za czym przemawia ulubiona przez niego forma wprowadzenia z w. 4-5 i w. 25. Stanowią one swoiste klamry, które w tejże perykopie pozwalają widzieć odrębną jednostkę literacką.

Obecna forma tekstu, jak to wykazali krytycy źródeł i historii redakcji, posiada tzw. „szwy”, które pozwoliły Łukaszowi połączyć wcześniejsze odręb-

29

G. Lüdemann, Early Christianity according to the Traditions in Acts. A Commentary, s. 98 .

30 S. Haar, Simon Magus: the First Gnostic?, s. 79-80. 
ne tradycje. Do istotnych problemów ujawnionych w tym kontekście badań zalicza:

- przeniesienie uwagi czytelnika z Filipa (w 8,5-13 główna osoba) na Piotra (w 8,14-25) oraz obecność Szymona w obu częściach;

- niejasne przerwanie sekwencji czasowej w 8,9-11 przez wzmiankę dotyczącą wcześniejszej działalności Szymona;

- wprowadzenie przerwy w 8,14-17 między chrztem a przyjęciem Ducha; po w. 13 Piotr i Jan przybywają z Jerozolimy i odgrywają kluczową rolę w przekazaniu daru Ducha Świętego (nie byli oni obecni przy chrzcie nawróconych „w imię Pana Jezusa”);

- opis Szymona w w. 13, jako ochrzczonego i towarzyszącego Filipowi, a jednocześnie żądnego władzy (w. 19-22), który potrzebuje skruchy;

- przedstawienie w w. 8,5-13 i 26-40 wyjątkowego materiału na temat Filipa, podczas gdy w. 14-25 były bardziej związane z Piotrowym cyklem;

- kwestia przyjmowania Ducha poruszona w w. 14-25 koresponduje z innym opowiadaniem Piotrowym zawartym w Dz 10,44-48; nie była ona obecna w cyklu Filipowym z 8,5-13 i 26-40;

- pojawienie się dwóch znamiennych wyrażeń w w. 5-13. Pierwsze do-

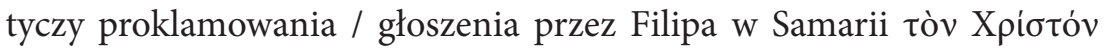
(8,5 [Chrystusa]), a następnie niezwykłe połączenie głoszenia dobrej nowiny o królestwie Bożym oraz o imieniu Jezusa Chrystusa $(8,12$ :

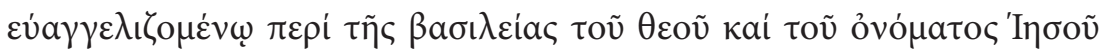

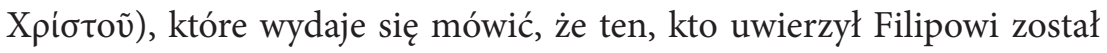

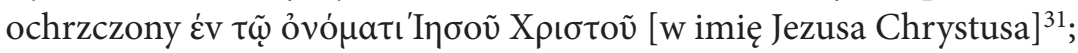

- podniesienie przez Lüdemanna ${ }^{32}$ kwestii, czy Łukasz mógł na podstawie znanej mu tradycji uczynić ironiczną aluzję do Heleny, znanej nam z późniejszych przekazów towarzyszki Szymona? Czy to ona kryje się pod Łukaszowym terminem érívoı (zamysł), gdy pisze o stanie serca

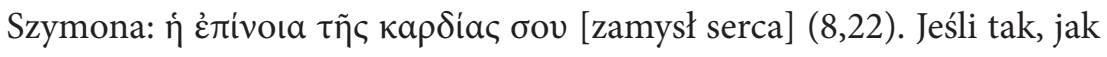
argumentował Lüdemann, dwa zasadnicze elementy (pre)gnostyckiej

31 Analiza języka w Dziejach Apostolskich ujawnia, że konstrukcja „w imię Jezusa Chrystusa” jest używana w opisach egzorcyzmów, uzdrawiających działań lub chrztu. Nato-

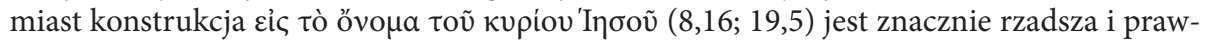
dopodobnie uwiarygadnia różne źródła Łuksza widoczne w w. 5-13 i 14-25.

32 G. Lüdemann, Early Christianity according to the Traditions in Acts. A Commentary, s. 96-98. 
religii szymoniańskiej znajdują się już w Dziejach Apostolskich: „bóg Szymon i jego syzygium (gr. syzygos = połączenie jarzmem), દ̇đívoı ”.

Idąc tym tropem badawczym, Dickerson skłonił się ku hipotezie, że fra-

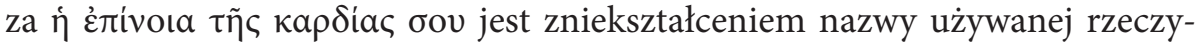
wiście przez Szymona na określenie Heleny ${ }^{33}$. Zrekonstruowana przez niego oryginalna fraza wyglądałaby następująco: $\eta \dot{~ \delta u ́ v a \mu ı ~ \tau o v ̃ ~} \theta \varepsilon o \tilde{v} \dot{\eta} \kappa a \lambda o v \mu \varepsilon \dot{v} \eta$

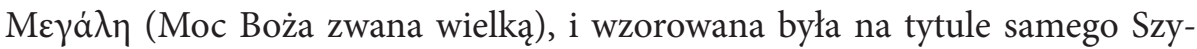

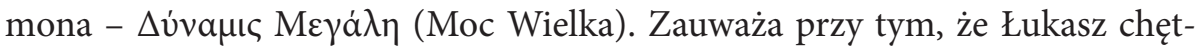

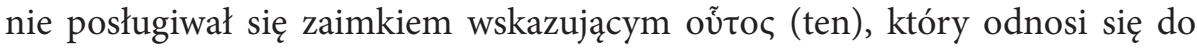
wcześniej wymienionego desygnatu lub czasami oznacza przejście do innego typu materiału ${ }^{34}$. Według niego Dzieje 8,10 są frazą zaczerpniętą ze źródła, na którym bazują w. 14-25. Oṽ̃oৎ w 8,10 sygnalizuje takie przejście, a tytuł

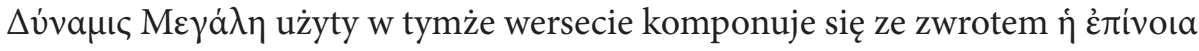

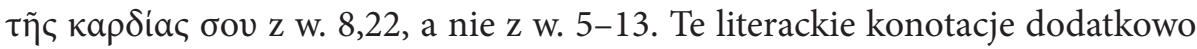
potwierdzają hipotezę, że Łukasz posługiwał się co najmniej dwoma źródłami, które zawierały opowiadania o Filipie i Szymonie (5-13) oraz Piotrze i Szymonie (14-25).

Konkluzja: Posługując się kryteriami wewnętrznymi, potwierdza się hipoteza, że Łukasz korzystał przynajmniej z dwóch źródeł: źródła Filipa / Szymona w w. 5-13 oraz Piotra / Szymona w 14-25. Istnieją ponadto dwa różne epizody w Dz 8,4-25: (1) o samarytańskiej misji Filipa, który jest jednym z uciekinierów z Jerozolimy po śmierci Szczepana $(8,4-13)$ oraz (2) o samarytańskiej misji Piotra (i Jana), którzy reprezentują wspólnotę jerozolimską $(8,14-25)$. Pierwszy passus spaja tematycznie rywalizacja pomiędzy Filipem a Szymonem, zaś drugi koncentruje się na ostrym sporze między Piotrem i Szymonem.

Tak więc krytyka źródeł i redakcji prowadzi do dwóch zasadniczych opinii: (1) w. 14-17 są konstrukcją Łukasza, łączącą dwie pierwotnie niezależne tradycje o konfrontacji Filipa i Szymona oraz Piotra i Szymona; (2) według drugiej opinii tylko jedno spotkanie z Szymonem znajduje podstawy w tradycji, drugie jest dziełem samego Łukasza. Jednak niezależnie od tradycji historycznych i stosowanych przez Łukasza technik łączenia materiałów, cała perykopa 8,4-25 - mimo różnych cech narracyjnych - została uformowana w dość spój-

33 P.L. Dickerson, The Sources of the Account of the Mission to Samaria in Acts 8:5-25, „Novum Testamentum” 39: 1997, s. 221.

34 Słowo to pojawia się 39 razy w Ewangelii Łukasza i 35 razy w Dziejach Apostolskich. 
ne opowiadanie stanowiące odrębną jednostkę literacką. Elementami ją spajającymi są: ta sama publiczność (lud Samarii - 5-7,12, 14, 16) obecna w obu scenach, wiodąca rola Szymona Maga $(10,13,18-19)$, zastosowanie naprzemienne jednego wzorca, raz obejmującego Szymona i chrześcijańskiego misjonarza Filipa (6-13), innym razem Piotra i Szymona (14-24) oraz w końcu wspólna dla obu scen sekwencja (w. 25$)^{35}$.

Z obecnego stanu badań, zwłaszcza dotyczących redakcji Dz 8,4-25, wynika, że istnieją wśród egzegetów niemałe rozbieżności dotyczące jej powstania. Autor Dziejów korzystał zapewne z różnych przekazów tradycji, dokonując jej kompilacji oraz uzupełniając własnymi interpolacjami, aby nadać spójność narracji. Nie ma też pewności, jakie jej elementy odzwierciedlają wydarzenia stricte historyczne, a jakie zostały przez Łukasza przydane, aby nadać opowiadaniu performatywny charakter i w adresatach wywołać przekonanie, iż Kościół, prowadząc misję wśród pogan, zdecydowanie odcinał się od magii, a niezwykłe czyny sprawiane przez ewagelizatorów domagały się ich właściwego zrozumienia w świetle wiary religijnej i pełniły funkcję znaków zwiastujących rzeczywistość nadprzyrodzoną, w którą wprowadzał faktycznie Jezus Chrystus, i pozwalał w niej w pełni uczestniczyć dzięki darowi Ducha Świętego. Już to skłania do bardzo ogólnej konkluzji, że Łukasz całej tej historii o Filipie, Szymonie i Piotrze nie wymyślił. Odwoływał się w niej do wcześniejszych przekazów, które wykorzystał do realizacji postawionego sobie celu natury literackiej i teologicznej. Obraz Szymona w Dziejach nie jest zatem stricte historyczny, podobnie jak i opis misji Filipa oraz Piotra i Jana w Samarii. Narracja Łukasza ma zatem charakter przede wszystkim performatywny, zmierzający do konfrontacji z wszechobecną magią, aby wspólnoty kościelne zdecydowanie z nią zerwały.

\section{Kontekst kulturowy narracji Dz 8,4-25}

Ósmy rozdział Dziejów z wątkiem dotyczącym Szymona, zwanego magiem, oraz Filipa i Piotra domaga się zrekonstruowania kontekstu kulturowego, który być może lepiej pozwoli zrozumieć sens interesującej nas narracji.

35 S. Haar, Simon Magus: the First Gnostic?, s. 83. 


\subsection{Samaria - miejsce prowadzonej misji Filipa i Piotra}

Ważne staje się określenie miejsca prowadzonej misji przez Filipa oraz Piotra i Jana. Autor Dziejów przekazuje, że „Filip przybył do miasta Samarii i głosił im Chrystusa" (Dz 8,4). Doprecyzowanie miejsca ich działalności, określenia, kim byli adresaci samarytańskiej misji ewangelizacyjnej Filipa, oraz kontekstu kulturowego nie jest bez znaczenia dla bliższego scharakteryzowania Szymona Maga i jego działalności. Wprawdzie Samarią nazywano w pierwszej połowie I wieku prowincję leżącą na północ od Judei, zamieszkałą głównie przez Samarytan, monoteistów czczących Boga Jahwe, ale nieprzejednanych wrogów Żydów - Judejczyków. Można się zastanawiać, czy to do nich skierowana była misja ewangelizacyjna Filipa? Dotychczasowe badania prowadzą do wniosku, że miejscem aktywności misyjnej, opisanej w ósmym rozdziale Dziejów, jest miasto Samaria, dawna stolica państwa północnego Izraela, zwane wówczas Sebaste, które odbudował Herod Wielki w latach trzydziestych p.n.e. Uczynił z niego greckie polis ze stadionem, teatrem, agorą, świątyniami ${ }^{36}$. Oznacza to, że Filip nie prowadził działalności w środowisku stricte samarytańskim, monoteistycznym, skupionym głównie w Sychem u stóp kultycznej dla Samarytan Góry Garizim, lecz w środowisku kosmopolitycznym, mieście zhellenizowanym, po części greckim, po części orientalnym, w którym mogła mieszkać bliżej nieokreślona grupa hellenizujących Samarytan, podobnie jak w Judei mieszkali hellenizujący Żydzi ${ }^{37}$. Oddawano w nim kult cesarzowi Augustowi (nazwa Sebaste wywodzi się od Sebastos = Augustus) $\mathrm{w}$ świątyni wybudowanej na jego cześć. Obok niej znajdowały się świątynie Kore i Dioskurów, odkryte przez archeologów w 1932 roku. Niewykluczone, że Szymon związany był ze świątynią Kore - jak sugeruje E. Dąbrowski - ponieważ Kore samarytańską (jak Artemidę w Efezie) nazywano Wielką (megale). Być może istnieje związek, pomiędzy tym, a określeniem Szymona przypomnianym w Dziejach, że „Ten jest ową wielką (megale) mocą bożą" (w. 10) ${ }^{38}$.

36 Por. E. Dąbrowski, Szymon Mag [IV aneks], w: Dzieje Apostolskie. Wstęp - przekład z oryginału - komentarz, Poznań 1961, s. 491-497.

37 Por. A. Parrot, Wśród zabytków Samarii i Jerozolimy, przeł. Edward Zwolski, Warszawa 1971, s. 70-82.

38 Por. E. Dąbrowski, Szymon Mag, s. 493. 


\subsection{Szymon z Samarii w przekazach chrześcijańskich II wieku}

Hipotezę o samarytańskim pochodzeniu Szymona zdaje się potwierdzać świadectwo Justyna, apologety chrześcijańskiego, który nie nawiązuje do Dziejów $\mathrm{w}$ tym, co pisze o stanie religijnym miasta Samarii i Szymonie. Jego przekaz jest niemal równoległy z Łukaszowym. W 1 Apologii powstałej, jak sugeruje Leszek Misiarczyk w latach $150-153^{39}$, pisze:

26.1. Po trzecie wreszcie, gdy po wstąpieniu Chrystusa do nieba demony skłoniły niektórych ludzi do tego, by sami nazwali się bogami, Wy nie tylko ich nie prześladowaliście, ale wręcz otoczyliście chwałą.

26.2. I tak oto niejaki Szymon z Samarii, ze wsi zwanej Gitton, który za cesarza Klaudiusza czynił mocą demonów magiczne sztuczki w Waszym cesarskim mieście Rzymie był uważany za boga. Ku jego to właśnie czci wystawiliście posąg na rzece Tybr pomiędzy dwoma mostami z takim oto napisem w języku łacińskim: "Simoni Deo Santo".

26.3. Prawie wszyscy Samarytanie i kilka innych narodów uznają go i czczą jako najwyższego boga. Niejaką zaś Helenę, która do niego dołączyła w tamtym czasie, wcześniej zaś przebywała w domu rozpusty, nazywają pierwszą jego myślą.

26.4. Wiemy także, iż niejaki Meander pochodzący również z Samarii, z miejscowości Kapparetaia, gdy stał się uczniem Szymona również i on został opętany przez demony i przybywszy do Antiochii wielu ludzi oszukał przy pomocy swojej magicznej sztuczki. Obiecywał on bowiem tym, którzy szli za nim, że nie umrą, a nawet jeszcze teraz żyją niektórzy jego zwolennicy, którzy nadal tak utrzymują.

26.5. Wreszcie niejaki Marcjon z Pontu, który do dziś jeszcze żyje i naucza swoich zwolenników, iż należy wierzyć w jakiegoś innego boga większego od Boga Stwórcy wszystkiego. [...]

26.6. Wszyscy ich zwolennicy, jak powiedzieliśmy, nazwani są chrześcijanami, choć nie wyznają tych samych nauk, podobnie zresztą jak owi filozofowie, którzy co prawda, różnią się w swoich poglądach, lecz określani są wspólnym mianem filozofii ${ }^{40}$.

Działalność Szymona sytuuje on w Rzymie, podobnie jak jego zwolenników szymonian. Justyn potępia go jako uprawiającego magię, którą zyskuje so-

39 Justyn Męczennik, 1 i 2 Apologia. Dialog z Żydem Tryfonem, tł. i oprac. L. Misiarczyk, Warszawa 2012, s. 17.

40 Zob. ibidem, s. 59-60. 
bie zwolenników. Niemniej nazywają się oni chrześcijanami, mimo że ich wiara odbiega od tej, którą głosi Justyn, trzymając się tradycji apostolskiej.

Po zapoznaniu się ze świadectwem Justyna powstaje pytanie, czy autor Dziejów nie znał dziejów Szymona Maga w Rzymie (po opuszczeniu Samarii) i głoszonych przez niego nauk wspieranych uprawianiem magii? Czy Łukasz świadomie przywołał tylko epizod z nim związany w Samarii, pozostawiając niewiadomą, jak zareagował on na skarcenie go przez Piotra i wezwanie do nawrócenia. Skądinąd znane są relacje, ukazujące dalszą jego działalność, która wpisuje się w rozwój ruchu gnostyckiego w II wieku, pozostającego w opozycji do ewangelizacji, zgodnej z tradycją apostolską reprezentowaną przez Piotra. Może w tak ujętej przez Łukasza narracji w Dziejach chodziło o podjęcie szerszej dyskusji ze zwolennikami magii (głównie poganami, ale i po części chrześcijanami) i wskazanie im drogi powrotu do wspólnot etnochrześcijańskich o tradycji apostolskiej.

Dziś wiadomo, że próba sprowadzenia ich w nurt (po)apostolski Kościoła w szerszej skali nie powiodła się. W latach osiemdziesiątych II wieku Ireneusz z Lyonu, który charakteryzuje różne herezje powstałe w łonie rozproszonych wspólnot chrześcijańskich, a wśród nich szymonian, którzy wywodzili się od Szymona Maga, jednoznacznie wskazał, że byli oni nadal aktywni oraz rozwijali praktyki i nauczanie Szymona:

Szymon, Samarytanin, był tym magiem, o którym Łukasz, naśladowca i uczeń apostołów, powiada: „Od dłuższego już czasu zamieszkiwał w mieście pewien człowiek o imieniu Szymon, który praktykował magię i zwodził Samarytan, twierdząc, że jest jakimś wielkim, a wszyscy, od dziecka aż do starca mówili: ,Oto jest Boża moc, która zwie się wielką. I tak cieszył się on ich uznaniem, gdyż uprawiając od dawna swe magiczne sztuczki, zdążył ich doprowadzić do szaleństwa”. I ten Szymon udał wierzącego, gdyż sądził, iż apostołowie własną swą mocą dokonują uzdrowień przy użyciu sztuki magicznej, a nie przy pomocy Bożej potęgi, oraz przez nałożenie rąk napełniają Duchem Świętym tych, którzy wierzą w Boga za pośrednictwem Jezusa Chrystusa, którego Ewangelię głoszą. Wydawało mu się, że czynią to oni dzięki głębszemu poznaniu sztuki magicznej i zaproponował Apostołom pieniądze, aby i jemu przekazali tę moc, tak by mógł udzielać Ducha Świętego każdemu, komu by zechciał. Usłyszawszy wówczas od Piotra: „Niech twoje pieniądze przepadną razem z tobą, chciałeś bowiem za pieniądze udzielać dar Boży. Nie masz żadnego udziału ani losu w tym przepowiadaniu, ponieważ twoje serce nie jest prawe przed Bogiem. Widzę, że pogrążony jesteś w żółci rozgoryczenia i spętany jesteś więzami niesprawiedliwości”. Odtąd jego wiara w Boga jeszcze bardziej osłabła, a on sam z większą zaciekłością postanowił wydać walkę apostołom, aby zyskać dla siebie 
więcej chwały i poświęcił się z pilnością zgłębianiu magii do tego stopnia, że wprawiał w osłupienie niemałą liczbę ludzi. (...) Wielu oddawało mu cześć jako Bogu, jednak on im wyjaśniał, że jest jedynie tym, który wśród Żydów objawił się jako Syn, w Samarii natomiast zstąpił jako Ojciec, do pozostałych zaś narodów przybył jako Duch Święty. Jednym słowem przedstawiał on siebie jako kogoś, kto jest Ojcem ponad wszelkimi rzeczami i pozwalał, by określano go wszelkimi możliwymi tytułami, jakich ludzie używają ${ }^{41}$. (I, 23,1)

Ireneusz dodaje następnie wiele innych szczegółów z nim związanych oraz przedstawia fragmenty jego poglądów, które zdobywały mu zwolenników. W efekcie - pisze Ireneusz - „Szymon Samarytanin, od którego biorą początek wszystkie herezje, utworzył sektę (...)" (I, 13,2). Wprawdzie nie wiemy, jak była ona liczna, ale istniała przynajmniej do przełomu II i III wieku, otaczając kultem Szymona (i Helenę), którego czcili pod postacią Zeusa (i Ateny). Jej członkowie mogli zatem znać pisma Łukasza, w tym opis z ósmego rozdziału Dziejów o swoim założycielu. Szymon miał też, oprócz uczniów, także następców, do których należeli Menander i Saturnin ${ }^{42}$.

\subsection{Magia w świecie antycznym vs. religia}

Autor Dziejów, charakteryzując postać Szymona Maga, stwierdza, że „dawniej zajmował się czarną magią”. Można pytać: co się kryje pod terminem „czarna magia"? Nowy Testament wyjątkowo tylko w tej księdze go przytacza. Biblia hebrajska, która stała się też księgą natchnioną chrześcijan, więcej mówi nam o praktykach magicznych, znanych wśród Izraelitów w przeszłości, zdecydowanie je potępiając ${ }^{43}$.

Księga Wyjścia 22,17 zakazuje w prawie rodzinnym obecności czarownic pośród Izraelitów (domyślnie: mogą stanowić zagrożenie dla młodych kobiet):

41 Zob. Ireneusz z Lyonu, Adversus haereses, przekł. J. Brylowski, Pelplin 2018, s. 71-72.

42 A.Z. Zmorzanka, Szymon Mag, w: Nowy słownik wczesnochrześcijańskiego piśmiennictwa, wyd. 2 przepr. i uzup. przyg. M. Starowieyski przy współ. W. Stawiszyńskiego, Poznań 2018, s. 907-908.

43 Por. X. Léon-Dufour, Magia, w: Słownik teologii biblijnej, red. naczelny X. Léon-Dufour; tł. i oprac. K. Romaniuk, 1973, s. 442-444; A.J. Avery-Peck, Magic, Magic Bowls, Astrology in Judaism, w: The Encyclopaedia of Judaism, vol. II, J-O, ed. by J. Neusner, A.J. Avery-Peck, W.S. Green, Leiden-Boston-Koeln 2000, s. 832 (832-844); S.I. Johnston, Magic, w: Religions of the Ancient World. A Guide, general ed. S.I. Johnston, Cambridge, Mas.-London 2004, s. 139-152. 
„Nie pozwolisz żyć czarownicy (dokładnie: „takiej, która się oddaje czarom”)"44. Oznacza to ostre potępienie magii, która nie powinna mieć miejsca na ziemi izraelskiej. Owa czarownica, to osoba podobna do szkodliwych demonów, zdolna do ściągania na ludzi różnego rodzaju nieszczęść, a nawet śmierci przy pomocy różnych czynności, słów i gestów ${ }^{45}$.

Księga Kapłańska dwukrotnie (19,31 i 20,6) potępia wróżbitów:

Nie będziecie się zwracać do wywoływaczy duchów ani do wróżbitów. Nie wypytujcie ich, bo staniecie się przez nich nieczystymi; Ja, Pan, jestem Bogiem waszym. $(19,31)$

Kto zaś zwróci się do wywoływaczy duchów i do wróżbitów, by naśladować ich w cudzołóstwie, to zwrócę swoje oblicze przeciwko takiemu i wytracę go spośród jego ludu. $(20,6)$

Hagiograf pragnie $\mathrm{w}$ ten sposób powiedzieć, że Jahwe brzydzi się takimi praktykami, zwłaszcza nekromancji, ponieważ szukanie odpowiedzi na istotne pytania człowieka u jasnowidzów, wróżbitów, wywoływaczy duchów jest lekceważeniem słowa Boga żyjącego ${ }^{46}$.

Jeszcze raz potępienie magii (wróżbitów, wieszczbiarzy, guślarzy, czarodziejów, zaklinaczy, wywoływaczy duchów, znachorów, wzywających zmarłych) odnajdujemy w Księdze Powtórzonego Prawa (18,10-12):

Niech nie znajdzie się u ciebie taki, który przeprowadza swego syna czy swoją córkę przez ogień, ani wróżbita, ani wieszczbiarz, ani guślarz, ani czarodziej, ani zaklinacz, ani wywoływacz duchów, ani znachor, ani wzywający zmarłych; gdyż obrzydliwością dla Pana jest każdy, kto to czyni, i z powodu tych obrzydliwości Pan, Bóg twój, wypędza ich przed tobą.

44 W przekazach tekstowych dotyczących 22, 17 istnieje różnorodność określeń: tekst masorecki mówi o czarownicy, Peszita syryjska o czarowniku, a Septuaginta o czarownikach.

45 Por. Ksiega Wyjścia. Wstęp - przekład z oryginału - komentarz, oprac. S. Łach, Poznań 1964, s. 222-223. Nie tylko prawo starożytnego Izraela potępiało magię. Również czyniły to przepisy prawne Kodeksu Hammurabiego nakładały karę śmierci na tego, kto podejrzany był o czary (zob. \$2; Kodeks Hammurabiego, przekład M. Stępień, Warszawa 1996, s. 80).

46 Por. Księga Kapłańska. Wstęp, przekład z oryginału, komentarz, oprac. A. Tronina, Częstochowa 2006, s. 291-292. 
Z tekstu wynika, że prawodawca zabrania Izraelitom posługiwać się środkami pogan do odgadywania przyszłości, nazywając je jednym zwrotem „obrzydliwość" narodów ${ }^{47}$. Karą za dopuszczanie się ich jest wypędzenie uprawiających ją tubylców z kraju, ponieważ Izraelici mają obowiązek szukania wyroczni tylko u Jahwe, a nie w naśladowaniu praktyk nie-Izraelitów.

$\mathrm{W}$ wielu innych wypowiedziach odnajdywanych w księgach Starego Testamentu magowie (nie mylić z astrologami) są pokonywani przez potęgę Boga Izraelitów. Patriarcha Józef tryumfuje nad czarownikami egipskimi ( $\mathrm{Rdz} 41)$, Mojżesz nad magami z Egiptu (Wj 7,10-13.19-23; 8,1-3.12-15; 9,8-12). Daniel kompromituje czarowników chaldejskich (Dn $2 ; 4 ; 5 ; 14)$. W Nowym Testamencie wszelkie praktyki magiczne odwodzą od służenia Bogu prawdziwe$\mathrm{mu}$, a ci, co dokonują rzeczy niezwykłych, w rzeczywistości fałszują naukę Bożą (Mt 24,34; Ap 16,12-16). Dlatego Bar-Jezus Elimas jest zmuszony do milczenia przez Pawła (Dz 13,6-11), podobnie czarodziejka z Filippi (16,16-24), albo egzorcyści żydowscy z Efezu (19,13-20). Pokusa uprawiania magii opisywana w pismach nowotestamentowych jest bardzo wielka. Łukasz mówi, że przystąpił z nią szatan do samego Jezusa, proponując Mu posłużenie się taką mocą, aby zaspokoić głód, przez co zdumiałby Żydów. Niemniej Jezus nie chciał przyjąć od szatana władzy nad światem (Łk 4,1-13).

Jak odbierali ten przekaz o zakazanych praktykach magicznych ewangelizowani politeiści ze świata grecko-rzymskiego? Na ile miał on wpływ na późniejsze gminy etnochrześcijańskie, które stanowiły mniejszościowe wspólnoty religijne wobec pogańskiego świata przenikniętego magią? Jak paradygmat nowej religijności chrześcijańskiej, w tym dotyczący uprawiania magii, był przez nie przyjmowany?

Gdy Ewangelia Jezusa zaczęła docierać do świata grecko-rzymskiego, na skutek aktywności misyjnej apostolskiego i postapostolskiego Kościoła, kondycja religijna przyszłych etnochrześcijan zdecydowanie różniła się od żydowskich odbiorców orędzia chrześcijańskiego (judeochrześcijan). Można się zastanawiać, jak można było do nich trafić z nauczaniem o żydowskim Mesjaszu, Synu Bożym, królestwie Bożym, zbawcy, zmartwychwstałym Panu, zapewniającym wierzącym w Niego zbawienie i życie wieczne, ostatecznym zwycięzcy nad wszelkim złem i zapanowaniu dobra? Czy postrzegano Go, jak czyniła

47 Por. Księga Powtórzonego Prawa. Wstęp - przekład z oryginału - komentarz-ekskursy, oprac. S. Łach, Poznań-Warszawa 1971, s. 206. 
większość pogan (ale także część Żydów nieprzyjmujących jego nauczania), jako maga?

W świecie grecko-rzymskim czasów Jezusa (poza obecnymi w nim Żydami, a było ich niemało) istnieli ludzie, których uznawano za wielkich nauczycieli i obdarzonych cudotwórczą mocą. Za takiego uchodził między innymi Apoloniusz z Tiany, opisany przez swego zwolennika Filostrata w Żywocie Apoloniusza. W niektórych źródłach rzymskich pojawiają się wzmianki o przypisywaniu niektórym osobom zdolności czynienia cudów: uciszania burzy, przepowiadania przyszłości, uzdrawiania ludzi, rozmnożenia chleba, wypędzania złych duchów, a nawet wskrzeszania zmarłych. Paradygmat opowiadań o nich był zazwyczaj ten sam. Ich urodziny związane były z cudownymi okolicznościami, a ziemskie życie kończyli wniebowstąpieniem. Na tym tle opowiadania o Jezusie, urodzonym w niezwykłych okolicznościach za sprawą Bożą, a później czyniącym niezwykłe znaki, dotyczyły jednego z wielu owych niezwykłych ludzi. Takie orędzie o Nim nikogo nie mogło dziwić ${ }^{48}$.

Inaczej też od ówczesnej mentalności kształtował się chrześcijański obraz świata. Grek i Rzymianin żył w przeświadczeniu, że ludzi otaczają istoty boskie, od których zależy ich los. Chcąc go zabezpieczyć, praktykowali czynności kultyczne, które różnie wyglądały w lokalnych społecznościach. Nie wpisywały się one w jakąś pancesarską religię, ujednolicony system religijno-doktrynalny, czy wspólny dla wszystkich obowiązujący etos. Form religijności było zatem wiele i żadna nie odwoływała się do świętych ksiąg, które standaryzowałyby indywidualną pobożność. Religijność ludzi wspierało państwo, bo jego pomyślność uzależniona była od łaskawości bóstw, dlatego finansowanie kultu stawało się powinnością tego organizmu, dbającego o dobro jego członków. Nie było też rywalizacji o wyłączność kultu oddawanego któremuś z bóstw (dążenie do monolatrii), ani tym bardziej o praktykowanie monoteizmu. Politeizm był powszechny i przez wszystkich aprobowany, za wyjątkiem Żydów (i Samarytan), którzy sami uprawiali monoteizm (w cesarstwie ich religia miała status licita dozwolona), a politeizm traktowali za zabroniony. Dbałość o osiągnięcie życia wiecznego niemal nie istniała. Obowiązywała zasada carpe diem i zainteresowanie dostatnim życiem teraźniejszym. Magia cieszyła się zainteresowaniem większości. Niedosyt jej uprawianiem powodował zainteresowanie kultami misteryjnymi, rozpowszechnionymi w całym cesarstwie. Każde misterium było

48 Por. K. Pilarczyk, Biblia chrześcijan. Wprowadzenie religioznawcze, historyczne i literackie, Kraków 2020, s. 73-75. 
unikalne, miało swój ośrodek, obyczaje i rytuał zazwyczaj otoczony nimbem tajemnicy. Wiele z nich koncentrowało się na micie śmierci i zmartwychwstania czczonego bóstwa. Odegranie takiego mitu miało uczestników przybliżać do tej niedostępnej rzeczywistości i utwierdzać w przekonaniu, że taki stan kiedyś sami osiągną. Najsłynniejsze z misteriów były ku czci greckiej bogini Demeter i jej córce Korze, odbywające się w greckim Eleusis, egipskie misteria ku czci Izydy i jej męża Ozyrysa oraz ku czci Dionizosa i perskiego boga Mitry. Nie można nie wspomnieć także misteria ku czci Artemidy efeskiej w Efezie i Koryncie.

Głębszą refleksję nad życiem, światem i osobą ludzką prowadzono w szkołach filozoficznych i instytucjach życia publicznego, na przykład w łaźniach miejskich. Wśród nich, w początkach nowej ery, wyróżniał się stoicyzm, platonizm i epikureizm (powstały już kilka wieków wcześniej), które wskazywały na potrzebę dobrego (etycznego) życia, aby osiągnąć szczęście. Ten dobrostan, jak głosiły szkoły, można było posiąść dzięki wysiłkowi intelektualnemu, pozwalającemu wniknąć w istotę rzeczywistości, oraz narzuconej sobie dyscyplinie. Co ciekawe, szkoły zabraniały swoistego polifonizmu filozoficznego. W tym zakresie, przeciwnie jak w obszarze religii, obowiązywała zasada ekskluzywizmu, która skłaniała do prowadzenia misji na rzecz danej szkoły.

$\mathrm{Na}$ tym tle warto rozwinąć wątek obecności magii w starożytnym świecie, z którego pochodziła większość etnochrześcijan. Zanim się nimi stali, kulturowo przynależeli do cywilizacji grecko-rzymskiej, której obce były poglądy żydów i (judeo)chrześcijan o magii, zawarte we wcześniej przytoczonych pismach sakralnych judaizmu i chrześcijaństwa. One same nie pozwalają na rozpoznanie wpływu magii na świat antyczny. Dopiero po opublikowaniu licznych (pozabiblijnych) źródeł do zagadnienia magii antycznej, zwłaszcza greckich, koptyjskich, hebrajskich i aramejskich oraz z papirusów demotycznych ${ }^{49}$, widać niezbicie, że magia była istotną częścią ludowej religii starożytności. Dlatego stała się przedmiotem zainteresowania badaczy, zwłaszcza od lat osiemdziesiątych XX wieku, egiptologów, historyków Grecji i Rzymu, historyków judaizmu, chrześcijaństwa, czy szerzej religioznawców. Ich badania doprowadziły między innymi do odnalezienia świadectw istnienia i rozpowszechniania magicznych praktyk także wśród Żydów i chrześcijan, którzy podtrzymywali je wbrew wspomnianym wyżej zakazom ${ }^{50}$. Rzymski pisarz Pliniusz Młodszy

49 Zob. A. Wypustek, Magia antyczna, Wrocław-Warszawa-Kraków 2001, s. 382-387. 
(I w. n.e.) wprawdzie twierdził, że najbardziej inteligentni ludzie jego czasu odrzucają wiarę w skuteczność magicznych formuł, niemniej nie zmienia to faktu, że magia i tak dominuje we wszystkich aspektach życia. Współczesne badania potwierdzają, że magia wykraczała poza granice społeczne, kulturowe, językowe, religijne, geograficzne i czasowe. Była niezwykle ważną częścią grecko-rzymskiego życia, stając się istotną częścią antycznej cywilizacji. Wprawdzie nie odnajdujemy o niej przekazów w antycznej literaturze grecko-rzymskiej, bo nie interesuje się ona pojedynczym człowiekiem, rzadko mówiąc o jego odczuciach, obyczajach, pragnieniach. W jego świecie rządził „niemal niepodzielnie mit, fikcja, propaganda, dydaktyka, schemat, antykwaryczna ciekawostka"51. Dopiero teksty magiczne oraz odczytywane w ich kontekście wzmianki o magii w Nowym Testamencie, dają wyraz prawdziwemu życiu starożytnego człowieka, niejako odzyskanemu przez badaczy w swej codzienności. Dziś nikt nie może poruszać się w świecie ewangelii, kanonicznych i apokryficznych dziejów apostolskich bez uwzględnienia wiedzy na temat ówczesnej magii. Odkrycie tekstów magicznych, zwłaszcza greckich, nierzadko porównywane jest do odkryć zwojów znad Morza Martwego i biblioteki z Nag Hammadi. Dało ono wgląd w ledwo dotąd uchwytne - jak twierdzi A. Wypustek - skądinąd zupełnie nieznane aspekty starożytnej religijności, z którą zapewne prowadził swoisty dyskurs autor Dziejów Apostolskich, próbując „rozprawić się” ze starożytną magią, której ikoną w pewnej mierze jest przypomniany przez niego Szymon Mag.

\subsection{Pomiędzy magią a cudami-znakami w ujęciu nowotestamentowym}

Dla symbolicznego i anonimowego Łukasza, autora Ewangelii i Dziejów Apostolskich, opisywane czyny Jezusa i ewangelizatorów, prowadzących działalność misyjną zgodną z nakazem Jezusa, były postrzegane jako cuda-znaki. Tak też rozumieli je członkowie powstających wspólnot chrześcijańskich. Natomiast ci, którzy odrzucali głoszoną przez nich Ewangelię, widzieli w nich magiczne praktyki, z którymi skądinąd byli obyci. Zderzenie tych postaw domaga się uchwycenia podstawowej różnicy pomiędzy cudami-znakami rozumianymi po chrześcijańsku, a magią, jak rozumiał ją świat nie-judeochrześcijański. Analizę tę ograniczymy do Łukaszowego rozumienia cudów-znaków w kontraście

51 Ibidem, s. 22. 
do wspomnianej przez niego magii w kontekście Dziejów, zwłaszcza ósmego ich rozdziału.

Cuda czynione przez Jezusa, a później przez apostołów w czasie misji ewangelizacyjnej, są w Nowym Testamencie postrzegane jako znaki, które wskazują na coś, co integralnie związane jest ze słowem Jezusa i apostołów. Cuda idą zatem $\mathrm{w}$ parze $\mathrm{z}$ głoszeniem (przepowiadaniem) Ewangelii ubogim. Posiadają one wymowę dla tych, którzy nie odrzucają z góry prawdy nauki Jezusa (Łk 16,31), lecz są na nią otwarci. Dlatego Jezus nie chce uczynić cudów na żądanie diabła, ludzi podstępnych, zazdrosnych (Łk 4,23), lekkomyślnych (23,8-9). Byłyby to uczynki daremne, nie posiadające zbawczej skuteczności. Poza tym cuda integralnie związane są ze słowami. Słowo narzuca się jako pierwszy i absolutnie konieczny znak przyjmowany ze względu na powagę osobistą głoszącego je oraz ze względu na wewnętrzną jakość tego słowa. Jest ono wypełnieniem wcześniejszego objawienia (Łk 16,31), które skłania słuchaczy do odpowiedzi wyrażonej w przyjęciu głoszonego orędzia za sprawą Ducha Świętego. Słowo w powiązaniu z czynionymi znakami stanowi kryterium odróżniania ich jako autentycznych lub fałszywych. Przyjęcie głoszonego słowa i skuteczność znaków mu towarzyszących dokonuje się w aurze wiary i wymaga od słuchaczy nawrócenia. Słowa powinny wzbudzać wiarę, ale do tego potrzebna jest gotowość zdania się na Boga i otwarcie się, które stanowi według Łukasza wyraz wiary poprzedzającej znaczenie czynionych niezwykłych cudów-znaków. Cuda czynione przez apostołów ukazują konkretną potęgę (dynameis) zbawczą Jezusa zmartwychwstałego (Dz 3,6.12.16) i doprowadzają ludzi do wiary oraz ją ugruntowują w nich ${ }^{52}$.

Zestawienie rozumienia cudu / znaku w nowotestamentowym ujęciu z magią uprawianą w starożytności prowadzi do wyspecyfikowania następujących różnic, które zapewne doprowadzą do lepszego zrozumienia Piotrowego potępienia zachowania Szymona, pragnącego kupić władzę przekazywania daru Ducha Świętego:

- magia koncentruje się na technicznej stronie wykonywanych rytualnie dokładnie określonych czynności, umożliwiających domniemany wpływ na siły wyższe w celu zapanowania nad biegiem wydarzeń dzięki wiedzy posiadanej przez wybrane jednostki (mag, szaman, czarownik,

52 P. Ternant, Cud, w: Słownik teologii biblijnej, s. 162-170. 
„filozof” $)^{53}$, religia zaś może się bez nich obejść lub stosować proste znaki (np. włożenie rąk na głowę);

- magia dążąc do opanowania nadnaturalnych sił stosuje przymus, manipulację, ubezwłasnowolniając człowieka; religia postrzega człowieka jako istotę zależną od mocy, pozostających poza zasięgiem jej wpływu, niemogącą manipulować bóstwem, lecz kierując się wolną wolą może oczekiwać łaski lub niełaski sił nadprzyrodzonych;

- magia chce osiągać cele materialne, indywidualne, konkretne jak uleczenie chorego lub chorobę wroga. Kalkuluje zysk maga lub jego klienta. To kryterium dzieli magię na czarną i białą ${ }^{54}$. Religia natomiast ukierunkowuje się na cele dalekosiężne (zbawienie, sens życia, łaskawość bóstwa), i wspólnotowe, zapewniając duchowy rozwój jednostce. Magia jest utylitarna, religia twórcza;

- magia jest często zakazana, a na pewno podejrzaną formą religijności (dewiacja prawdziwej religii). Jej cele są sprzeczne z założycielską ideą wspólnoty, z jej porządkiem moralnym, obyczajowym, prawnym. Jeżeli nie jest wprost antyspołeczna, jest zapewne aspołeczna, dlatego mag nie ma kościoła, gminy, wspólnoty; ma tylko klientów (Durkheim) i zwolenników. Religia natomiast spełnia pożyteczne, społeczne funkcje, przyczynia się do zacieśniania więzów wspólnotowych i solidarności. Magia narzuca model relacji profesjonalista i klient, religia preferuje model pasterz - stado, kapłan / starszy - Kościół (wspólnota). Różnice między nimi sprowadza się do kontrastu między działaniem indywidualnym a wspólnotowym ${ }^{55}$.

Ta teoretyczna refleksja nad relacją magii do religii pozwala lepiej zrozumieć Łukaszowy opis dotyczący Szymona Maga i istotę konfliktu między nim a Piotrem. Piotrowy model ewangelizacji, w ujęciu Dziejów, w żadnej mierze

53 Por. P. Jaroszyński, Magia, w: Powszechna encyklopedia filozofii, t. 6, Lublin 2005, s. 681; A. Wierciński, Magia i religia. Szkice z antropologii religii, wyd. 3 rozsz. i popr., Kraków 2010, s. 135.

54 Czarna magia naruszała prawa niepisane, podważała tradycyjny model obywatelskiej pobożności, pobożności wspólnoty, polis. Mag często oczekiwał rezultatów nieetycznych i nielegalnych. $Z$ jej pomocą człowiek chciał zapanować nad bóstwem czy demonem, a nie przyjmować wobec nich korną postawę, czego domagałaby się religia, choćby państwowa obowiązująca w imperium rzymskim.

55 Por. A. Wypustek, Magia antyczna, s. 27-28. 
nie nawiązuje do antycznej magii, wymyślnych technik, przez nią stosowanych, wykorzystania ich do wpływania na to, co boskie. Sam Piotr nie był magiem, lecz prostym rybakiem, który został powołany przez Jezusa do świadczenia o Nim i budowania wspólnot złożonych z Jego wyznawców. Sam był przekonany o tym, że sukcesy misyjne zawdzięczano nie dzięki ludzkiej aktywności i umiejętności ewangelizacyjnych, lecz dzięki mocy głoszonego słowa i darowi Ducha Świętego, którego pierwsze zesłanie znalazło się u fundamentów tej misji (Dz 2). Czynione przez Piotra i innych ewangelizatorów znaki / cuda były spontaniczne, zakorzenione $\mathrm{w}$ przeświadczeniu, że ich moc sprawczą biorą z wiary w Jezusa Chrystusa, a nie z tajemnej wiedzy, którą zdobyli. Nigdy nie posługiwali się w swej działalności przemocą, ubezwłasnowolnianiem swych słuchaczy, lecz oczekiwali od obdarowanych przyzwolenia, współdziałania i wiary religijnej, do której przez głoszone słowo wzywali, pokazując zarazem źródło ich działania. Przy tym nie byli nastawieni na jakikolwiek zysk. Czynili wszystko w imię Jezusa z myślą o zbawieniu człowieka, odkryciu nowego sensu życia dzięki zjednoczeniu z tym, który stał się przez śmierć na krzyżu i zmartwychwstanie Soterem (Zbawcą), zdolnym pojednać ludzi z Bogiem przez odpuszczenie grzechów oraz okazanie im łaskawości (miłości) w najwyższym stopniu, tj. przez miłosierdzie. Tworzone przez ewangelizatorów wspólnoty, nie kierowały się zakazanymi zasadami, lecz - jak to ujmuje Łukasz - trwały na modlitwie, łamaniu chleba (eucharystia), dzieląc się posiadanymi dobrami (Dz 5). Ich przełożeni dbali o zachowywanie ładu moralnego, trzymanie się ewangelicznych zasad życia, dobre obyczaje, solidarność ewangeliczną, która miała swoją głębię religijną, co wynikało z przyjętego chrztu, włączającego do wspólnoty i jednoczącego każdego jej członka z osobą Jezusa Chrystusa za sprawą Ducha Świętego. Na tym tle Szymon, przez swe przywiązanie do uprawianej magii, odbiegał od chrześcijańskich ideałów i dlatego - w ujęciu Dziejów - tak ostro został skarcony przez Piotra i wezwany do nawrócenia. Nie wpisywał się bowiem w przyjęty przez apostołów model głoszenia Ewangelii, a wręcz go wypaczał.

\section{Wnioski}

Wracając do pytań postawionych na wstępie, można podjąć próbę określenia miejsca narracji o Szymonie w strukturze Dziejów Apostolskich i jej Łukaszowego znaczenia. Epizod Szymona został wpisany przez autora Dziejów w misję 
ewangelizacyjną prowadzoną w Samarii, skierowaną głównie do wyznawców politeizmu (pogan), a nie ściśle monoteistycznych Samarytan. Polegała ona na „głoszeniu im Chrystusa” i „dobrej nowiny o królestwie Bożym” (Dz 8,5.12), czyli ukazania Jezusa jako Mesjasza i zmartwychwstałego Pana. W koncepcji całej księgi jest ona wyrazem realizacji misji powierzonej przez Jezusa apostołom, polegającej na tym, że mają być Jego świadkami w Jerozolimie, Judei, Samarii aż po krańce ziemi. Przepowiadanie kerygmatyczne Filipa, a następnie Piotra, wpisuje się w nią. W ten sposób Łukasz pokazał, jaka była droga Ewangelii do chrześcijan drugiego pokolenia, do których jego księga została skierowana. To dzięki wysiłkom takich osób jak Filip i Piotr zawdzięczali oni to, że stali się chrześcijanami, co pozwoliło im jednocześnie odkryć spójny Boży plan zbawienia, którym zostali objęci i nadal był on względem nich realizowany. Sama księga Łukasza do nich skierowana miała przede wszystkim pełnić funkcję performatywną, to znaczy kształtować ich wiarę, wpływać na duchowość chrześcijan drugiej i trzeciej generacji, utrwalać instytucje kościelne, których korzenie znajdowały się w Kościele apostolskim, zapewniając ciągłość rozwoju wspólnocie mającej rodowód bosko-ludzki.

Misji Filipa w Samarii - jak to przedstawia Łukasz - towarzyszyły liczne znaki i cuda. Pod ich wpływem przyjął chrzest również znany w Samarii mag, Szymon. Jego obraz przedstawiony w Dziejach nie jest stricte historyczny, ale ma zakorzenienie $\mathrm{w}$ przedłukaszowej tradycji, którą spożytkował Łukasz w opracowanym przez siebie opowiadaniu, tworzącym w Dziejach spójną jednostkę literacką (Dz 8,4-25). Poczesne w niej miejsce zajmują Filip, Piotr i Szymon. W pierwszej fazie opowiadania Szymon Mag ukazany został jako neofita, którego swym przepowiadaniem pozyskał dla Chrystusa Filip. Na tym etapie nie dostrzega się żadnych konfliktów między nimi. Wprost przeciwnie, widać w tym sukces misyjny Filipa, który znanego w środowisku samarytańskim czarnoksiężnika przekonał słowem i czynami do przyjęcia wiary Chrystusowej i chrztu. Dla później żyjących etnochrześcijan, którzy sami przed nawróceniem także zapewne uprawiali magię, jak większość ludzi antyku grecko-rzymskiego, był to silny argument za tym, że Ewangelia jest w stanie pokonać magię i nie ma $\mathrm{z}$ nią nic wspólnego.

Epizod Szymona, rozwijany w Łukaszowym opowiadaniu, ma następnie drugą odsłonę. Kiedy pojawia się w Samarii u boku Filipa Piotr i dopełnia misji diakona przez udzielanie ochrzczonym Ducha Świętego w geście nałożenia na nich rąk, dochodzi do konfliktu między Apostołem a Szymonem. Jego powodem było pragnienie kupienia przez maga od Piotra władzy udzielania 
Ducha. Przekaz Dziejów z tym związany jest jednoznaczny: Boże dary nie są na sprzedaż i do utylitarnego wykorzystywania. Ma on też dalekosiężne skutki. Kiedy spotyka się z nim drugie (i następne) pokolenie chrześcijan, odkrywa ono zdecydowane odcięcie się wspólnot kościelnych od magii i wszelkich praktyk magicznych, szerzących się w świecie antycznym. Konkludując, można powiedzieć lapidarnie, że Ewangelia pokonuje magię, pokazując i w tym swą siłę oddziaływania zdolną zmieniać świat i prowadzić do odkrywania zbawczej mocy Jezusa Chrystusa.

Natomiast znamienna jest zaproponowana przez autora Dziejów ocena czynu Szymona. Z jednej strony Łukasz zdecydowanie go potępia (przekleństwo Piotra), ale jednocześnie pozostawia Szymonowi drogę powrotu do jedności ze wspólnotą chrześcijańską, co wyraża się w prośbie maga skierowanej do ewangelizatorów: „Módlcie się do Pana, aby nie spotkało mnie nic z tego, co powiedzieliście” (Dz 8,24). Również słowa Piotra wypowiedziane zostają do Szymona w tym samym duchu: „Odwróć się więc od swego grzechu i proś Pana, a może Ci odpuści twój zamiar” (Dz 8,22). Pamiętając o dalszych losach Szymona, który prowadził swą działalność w opozycji do Kościoła apostolskiego, nadal praktykując magię, o czym zapewne autor Dziejów wiedział, zastanawia zakończenie opowiadania o Szymonie w ujęciu Łukaszowym. Szymon wprawdzie został potępiony, ale nie definitywnie. Pozostawiona mu została droga nawrócenia i zademonstrowana jego dobra wola w tym zakresie wyrażona w prośbie o modlitwę za niego. To bez wątpienia zaskakuje i zdumiewa. Zapewne Łukasz pragnął przekazać w ten sposób drugiemu pokoleniu chrześcijan, że dla wszystkich uprawiających magię, a było to jak wówczas powszechne zjawisko, jest szansa na odstąpienie od tych praktyk i powrót do etosu chrześcijańskiego w rozumieniu apostolskim. Przez wprowadzenie do Dziejów epizodu o samarytańskim czarnoksiężniku ich autor chciał ukazać otwartość Kościoła na dewiacje religijne i pozareligijne związane $\mathrm{z}$ wszechobecną magią, dowodząc, że Ewangelia jest w stanie je pokonać, choć jest to zależne od okazania dobrej woli przez ewangelizowanych, ponieważ tylko ten akt osoby ludzkiej otwiera ją na działanie Ducha Świętego. Narracja o Szymonie Magu znanym z Dziejów Apostolskich może być zaliczona do pouczających przekazów paradygmatycznych, których odnajdujemy w tym piśmie wiele ${ }^{56}$.

56 Por. A.J. Najda, Historiografia paradygmatyczna w Dziejach Apostolskich, Warszawa 2011, passim. 


\section{Bibliografia}

\section{Źródła}

Dzieje Piotra Apostoła i Szymona, tłum. Zbigniew Izydorczyk i Mirosław Bielewicz, oprac. Zbigniew Izydorczyk, Warszawskie Studia Teologiczne 16, 2003, s. 101-150.

Ireneusz z Lyonu, Adversus haereses, przekł. Jarosław Brylowski, Pelplin 2018.

Justyn Męczennik, 1 i 2 Apologia. Dialog z Żydem Tryfonem, tł. i oprac. Leszek Misiarczyk, Warszawa 2012.

Kodeks Hammurabiego, przekład Marek Stępień, Warszawa 1996.

Księga Kapłańska. Wstęp, przekład z oryginału, komentarz, oprac. Antoni Tronina, Częstochowa 2006.

Księga Powtórzonego Prawa. Wstęp - przekład z oryginału - komentarz - ekskursy, oprac. Stanisław Łach, Poznań-Warszawa 1971.

Księga Wyjścia. Wstęp - przekład z oryginału - komentarz, oprac. Stanisław Łach, Poznań 1964.

Nowy Testament grecki i polski, Nestle-Aland; red. wyd. Roman Bogacz, Roman Mazur, [tekst grecki] wyd. 28 popr., Poznań 2017.

\section{Opracowania}

Acts and Christian Beginnings: the Acts Seminar Report, ed. by D.E. Smith and J.B. Tyson, Salem, Oregon 2013.

Aland Barbara, Die Gnosis, Stuttgart 2014.

Aune D.E., The New Testament in Its Literary Environment, Philadelphia 1987.

Avery-Peck Alan J., Magic, Magic Bowls, Astrology in Judaism, w: The Encyclopaedia of Judaism, vol. II, J-O, ed. by Jacob Neusner, Alan J. Avery-Peck, William Scott Green, Leiden-Boston-Koeln 2000, s. 832-844.

Barrett Charles, A Critical and Exegetical Commentary on the Acts of the Apostles, 1 vol., Preliminary Introduction and Commentary on Acts I-XIV, Edinburgh 1994.

Barrett Charles, A Critical and Exegetical Commentary on the Acts of the Apostles, vol. I, Preliminary Introduction and Commentary on Acts IX-IV, Edinburgh 1994.

Bauernfeind Otto, Die Apostelgeschichte (ThHK 5), Leipzig 1939.

Bruce Frederick F. (jm), Dzieje Apostolskie, w: Słownik wiedzy biblijnej, red. nauk. Bruce M. Metzger, Michael D. Coogan, wyd. 3, Warszawa 1999, s. 128-132.

Chrostowski Waldemar, Szymonianie, w: Encyklopedia katolicka, Lublin 2013, t. 19, kol. 231-232.

Conzelmann Hans, Acts of the Apostles, trans. J. Limberg, A.T. Kraabel, D.H. Juel, Philadelphia 1987. 
Cullmann Oskar, Samarien und die Anfange der christlichen Mission. Wer sind die

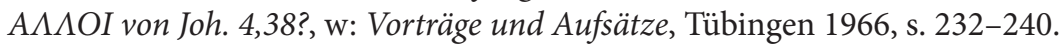

Daniélou Jean, Teologia judeochrześcijańska. Historia doktryn chrześcijańskich przed soborem nicejskim, przekł. Stanisław Basista, Kraków 2002.

Dąbrowski Eugeniusz, Szymon Mag [IV aneks], w: Dzieje Apostolskie. Wstęp - przekład z oryginału - komentarz, Poznań 1961, s. 491-497.

Dickerson P.L., The Sources of the Account of the Mission to Samaria in Acts 8:5- 25, Novum Testamentum 39, 1997, s. 210-134.

Dillon Richard J., Dzieje Apostolskie, w: Katolicki komentarz biblijny, red. Raymond E. Brown, Joseph A. Fitzmyer, Roland E. Murphy; red. wyd. pol. Waldemar Chrostowski, Warszawa 2001, s. 1177-1250.

Gryglewicz Feliks, Dzieje Apostolskie, w: Encyklopedia katolicka, t. 4, Lublin 1983, kol. 575-578.

Haar Stephen, Simon Magus: the First Gnostic? (Beihefte zur Zeitschrift für die neutestamentliche Wissenschaft und die Kunde der älteren Kirche, Bd. 119), Berlin-New York 2003.

Haenchen Ernst, The Acts of the Apostles. A Commentary, Oxford 1971.

Ireneusz z Lyonu, Adversus haereses, przekł. Jarosław Brylowski, Pelplin 2018.

Jaroszyński Piotr, Magia, w: Powszechna encyklopedia filozofii, t. 6, Lublin 2005, s. 681$-686$.

Johnston Sarah Iles, Magic, w: Religions of the Ancient World. A Guide, general ed. Sarah Iles Johnston, Cambridge, Mas.-London 2004, s. 139-152.

Justyn Męczennik, w: Nowy słownik wczesnochrześcijańskiego piśmiennictwa, wyd. 2 przepr. i uzup. Marek Starowieyski przy współ. Wojciecha Stawiszyńskiego, Poznań 2018, s. 566-569.

Koch Dietrich-Alex, Geistbesitz, Geistverleihung und Wundermacht. Erwägungen zur Tradition und zur lukanischen Redaktion in Act 8, 5-25, „Zeitschrift für Neutestamentlichen Wissenschaft" 77, 1986, s. 67-80.

Kochanek Piotr, Szymon Mag, w: Encyklopedia katolicka, Lublin 2013, t. 19, kol. 229-230 .

Léon-Dufour Xavier, Magia, w: Słownik teologii biblijnej, red. naczelny Xavier Léon-Dufour; tł. i oprac. Kazimierz Romaniuk, 1973, s. 442-444.

Lüdemann Gerd, Early Christianity according to the Traditions in Acts. A Commentary, Minneapolis 1989.

Lüdemann Gerd, Untersuchungen zur simonianischen Gnosis (GTA 1), Göttingen 1975. Markschies Christoph, Die Gnosis, 4. Aufl., München 2018.

Miziński Artur, Symonia, w: Leksykon Prawa Kanonicznego, red. Mirosław Sitarz, Lublin 2019, kol. 2686-2689.

Najda Andrzej Jacek, Historiografia paradygmatyczna w Dziejach Apostolskich, Warszawa 2011.

Parrot Andrè, Wśród zabytków Samarii i Jerozolimy, przeł. Edward Zwolski, Warszawa 1971. 
Pilarczyk Krzysztof, Biblia chrześcijan. Wprowadzenie religioznawcze, historyczne i literackie, Kraków 2020.

Pilarczyk Krzysztof, Wokół problemu datacji Dziejów Apostolskich, Wrocławski Przegląd Teologiczny 23, 2015, nr 3, s. 75-94.

Rudolph Kurt, Simon - Magus oder Gnosticus? Zum Stand der Debatte, Theologische Rundschau 42, 1977, s. 279-359.

Schneider Gerhard, Die Apostelgeschichte (Herder Theologischer Kommentar zum Neuen Testament 5), Bd. I, Freiburg-Basel-Wien 1980.

Ternant Paul, Cud, w: Słownik teologii biblijnej, red. naczelny Xavier Léon-Dufour; tł. i oprac. Kazimierz Romaniuk, 1973, s. 162-170.

Tuzlak Ayse, The Magician and the Heretic: the Case of Simon Magus, w: Magic and Ritual in the Ancient World, Brill 2001, s. 416-426.

Waitz Hans, Die Quelle der Philippusgeschichten in der Apostelgeschichte, Zeitschrift für Neutestamentlichen Wissenschaft 7, 1906, s. 352-353.

Walburn Andrew, Początki chrześcijaństwa. Esseńskie misterium, gnostyckie objawienie, chrześcijańska wizja, Warszawa 1998.

Wellhausen Julius, Kritische Analyse der Apostelgeschichte (AGG 15), Berlin 1914.

Wierciński Andrzej, Magia i religia. Szkice z antropologii religii, wyd. 3 rozsz. i popr., Kraków 2010.

Wypustek Andrzej, Magia antyczna, Wrocław-Warszawa-Kraków 2001.

Zmorzanka Anna Z., Szymon Mag, w: Nowy słownik wczesnochrześcijańskiego piśmiennictwa, wyd. 2 przepr. i uzup. przyg. Marek Starowieyski przy współ. Wojciecha Stawiszyńskiego, Poznań 2018, s. 907-908.

Zmorzanka Anna Z., Szymon Mag, w: Powszechna encyklopedia filozofii, Lublin 2009, t. 9, s. 318-320. 